\title{
Atmospheric electricity at Durham: the scientific contributions and legacy of J. A. ("Skip") Chalmers (1904-1967)
}

\author{
Karen L. Aplin \\ Department of Physics, University of Oxford, Denys Wilkinson Building, Keble Road, Oxford OX1 3RH, UK \\ Correspondence: Karen L. Aplin (karen.aplin@physics.ox.ac.uk)
}

Received: 13 November 2017 - Revised: 31 January 2018 - Accepted: 5 February 2018 - Published: 9 March 2018

\begin{abstract}
John Alan Chalmers made major contributions to atmospheric electricity over almost 40 years spent at Durham University, UK. He is particularly remembered in the atmospheric science community for his accessible and insightful textbook, Atmospheric Electricity, and his work on corona currents, which are still regularly cited. He also supervised over 35 research students. This article discusses his background, scientific contributions, and significant legacy to modern atmospheric science within the context of a long and productive career spent at one of England's principal northern universities.
\end{abstract}

\section{Introduction}

John Alan Chalmers ${ }^{1}$ worked at the UK's University of Durham from 1928 until his death in 1967. During his appointment the Physics Department was founded, in 1939. He was a leading researcher in atmospheric electricity, establishing one of the most productive and long-lived research groups of the 20th century, publishing around 90 refereed papers and a classic textbook. He did much to shape the modern subject of atmospheric electricity, particularly through international networking and carefully analysed measurements of atmospheric electrical parameters in many different meteorological conditions. He supervised numerous research students who went on to become successful scientists in atmospheric electricity, meteorology, solid earth geophysics, and industry. Despite this, and the continued regular use of his textbook by atmospheric electricity researchers to this day, he remains under-appreciated in the broader geophysical community, something this paper seeks to address. Separately from atmospheric electricity, the study of the career

\footnotetext{
${ }^{1}$ J. A. Chalmers was known by his second name, Chalmers and informally to everyone who knew him as "Skip", the commonly used nickname for the leader of a Scout troop. Here he will simply be called Chalmers.
}

of a geophysical scientist at a provincial UK university in the mid-20th century is an under-explored topic.

\section{Chalmers' education and early life}

John Alan Chalmers was born in London on 29 September 1904 to Stephen and Clara Chalmers. He had a younger brother, Bruce (1907-1990), and a sister, Marian. There was science in the family: Stephen Chalmers led the department of technical optics at Northampton Polytechnic Institute (Census, 1911), and Clara's brother Walter Rosenhain was a leading metallurgist at the National Physical Laboratory (Turnbull, 1999). (Like his uncle, Bruce later became a metallurgist and ultimately a Harvard University professor Turnbull, 1999.)

Chalmers showed early talent, winning a scholarship to Highgate School, where he studied as a day pupil and was something of an all-rounder, winning prizes for mathematics in 1919, science in 1920, and English in 1923. He also participated in sport, and is mentioned in the archives and the school magazine for his performance in long jump, football, cricket, and cross-country running (The Cholmeleian, 1923a, b; Michele Losse, personal communication, 2017). He performed so well in his final examinations at Highgate that he was given extra money by the school to support the scholarship he had already earned to study Natu- 


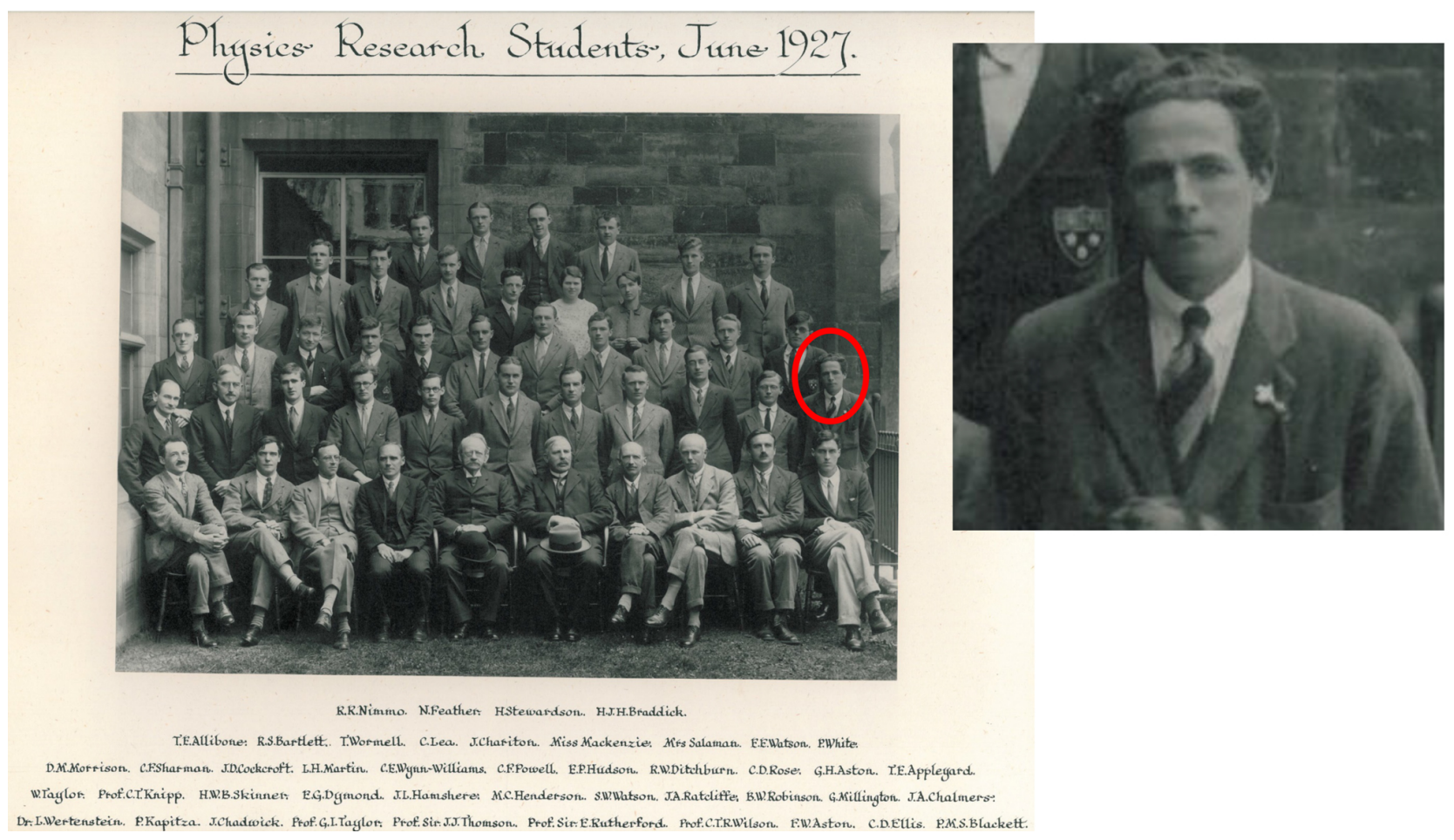

Figure 1. Staff and research students of the Cavendish Laboratory in 1927, with Chalmers inset. (Picture provided with the kind permission of Prof. M. Longair, Cavendish Laboratory.)

ral Sciences at Queen's College, Cambridge (Losse, personal communication, 2017). He achieved a first class degree in 1926 (Rochester and Hutchinson, 1967), and stayed at the Cavendish Laboratory (as Cambridge's Physics Department was and is still known) for postgraduate study.

At this time the Cavendish would have been an exciting place to study physics, even as an undergraduate. For example, the syllabus for 1927-1928 shows that undergraduates were offered courses such as Atmospheric Electricity and Condensation on Nuclei with Prof. C. T. R. Wilson, Ionisation and Radioactivity with Prof. E. Rutherford, and Advanced Quantum Mechanics with a young researcher, Dr. P. A. M. Dirac (Longair, 2006). Figure 1 shows the staff and research students at the Cavendish Laboratory in 1927. The Cavendish Laboratory's site at Free School Lane was notoriously cramped at this time (Longair, 2006), so it is highly likely that Chalmers would have had ample opportunity to talk to almost everyone in the photo, an exceptional concentration of experts. As will be discussed later, this no doubt contributed to his training in both experimental and theoretical physics. As Rutherford, who was Chalmers' nominal supervisor, was President of the Royal Society, Jacksonian Professor of Physics, and Head of Department at the time, much of the day-to-day supervision of Chalmers' work was provided by a new lecturer, Dr. C. Ellis, who is acknowledged in
Chalmers' thesis, completed in 1930 (no. 36) ${ }^{2}$. Chalmers had left Cambridge in 1928 to take up a lectureship at Durham University, where he spent the rest of his career.

\section{Career at Durham University}

Durham University had created a science site and began awarding its own science degrees in 1924; science had previously been taught at Newcastle, then part of Durham University (Durham University Archive, 2008; Tuck, 1995). No records have been found about Chalmers' appointment, but it seems likely that he was taken on by J. E. P. Wagstaff, a physicist with research interests in electrostatics and atmospheric physics (see e.g. Bloomfield, 1948) who had been hired in the 1920s when science was first established in Durham (Tuck, 1995). A separate Physics Department, with Wagstaff as its head, was not set up until 1939 (Durham University Archive, 2008).

Chalmers was heavily loaded with teaching and administration at Durham; he lectured, including giving a course on atmospheric electricity, and demonstrated in the third year teaching laboratories for many years. He supervised many (at least 35) doctoral and MSc students. Later in his career he led discussions on the format of a new BSc degree, and

\footnotetext{
${ }^{2} \mathrm{~A}$ full bibliography of Chalmers' publications is provided as a numbered alphabetical list in Appendix A. They are referred to in the text by their number in this list.
} 
ultimately became Dean of Science (Rochester and Hutchinson, 1967). He was promoted to Senior Lecturer in $1947^{3}$ and Reader in $1957^{4}$. He had strong international connections, speaking at and chairing a discussion at a conference on atmospheric electricity held at Wentworth-by-the-Sea, New Hampshire, USA, in 1954 (Holzer and Smith, 1955), and attending a subsequent conference at the same location in 1958 (Smith, 1958) ${ }^{5}$. He was also a Ford Foundation Visiting Professor at the University of Ibadan in Nigeria during a sabbatical in 1964 (no. 68).

Chalmers applied for the title of Professor in 1965 (Durham University Archive, 1965). Despite strong support from the Head of Department, and two strong external references from Prof. Basil Schonland FRS (who will be discussed in Sect. 4, but who was by then retired from a distinguished career) and Prof. P. J. Nolan (Dublin), there was some discussion over whether Chalmers' work and reputation were strong enough for the title. The main reason for this was a lukewarm reference from Prof. B. J. Mason, an ambitious man who was then a professor at Imperial College, though he would soon leave to become the youngest ever Director General of the Meteorological Office (Browning, 2015). He wrote,

"I cannot pretend that Chalmers' work shows the outstanding quality and originality that one would look for in considering a much younger man...".

As a result, an additional opinion was sought from Dr. T. Wormell (also mentioned in Sect. 4), who was then a Visiting Professor at New Mexico, and who strongly backed Chalmers:

"Doctor Chalmers and his work and books are very widely known. I find that whenever I visit an Institution abroad, with interests in this field, one of the first questions asked is whether I know him, or if

\footnotetext{
${ }^{3}$ At the outbreak of the Second World War in 1939, Chalmers was 34, within the conscription age band. During the war his papers moved abruptly away from atmospheric electricity to more applied research on contact potentials, perhaps implying he was involved with war-related work based at Durham.

${ }^{4}$ The career structure at UK universities in the mid-twentieth century was typically appointment at Lecturer level, followed by promotion to Senior Lecturer or Reader. These were roughly equivalent, though as Senior Lecturer was more teaching-focused and Reader more research-focused, Reader was often seen as more prestigious. The personal title of Professor was relatively rarely awarded. It was possible to be promoted from Senior Lecturer to Reader, like Chalmers, or, less commonly, from Senior Lecturer to Professor.

${ }^{5}$ These conferences later became the International Conference on Atmospheric Electricity (ICAE), which is still held every 4 years and supported by the International Commission on Atmospheric Electricity, part of the International Association of Meteorology and Atmospheric Sciences (IAMAS), which in turn is part of the International Union of Geodesy and Geophysics (IUGG).
}

that is considered a superfluous question, an enquiry as to his health and recent activities."

This must have satisfied the Committee, who awarded Chalmers the title of Professor in 1965 (Durham University Records, 1965). Sadly, his professorial career was to be short-lived as he died after a short illness on 14 March 1967. After his death, a bottle of radioactive paint (used in instrumentation for atmospheric electricity measurements) and an original reference letter from Lord Rutherford were found in his desk (Harrison, 2018).

\section{Contributions to atmospheric electricity}

It is not clear what inspired Chalmers to start working on atmospheric electricity in around 1932 (Durham University Archive, 1965). His thesis (no. 36) shows no evidence of any atmospheric research interests, although one chapter is on measurements of the spectrum of beta-rays, which were detected at that time by their effects on the air conductivity, measured with a gold leaf electroscope. Chalmers would therefore have become familiar with the sensitive measurements needed for atmospheric electrical research through his experimental work. There was active research on atmospheric electricity at the Cavendish, led by C. T. R. Wilson, who was awarded the Nobel Prize in 1927 for inventing the cloud chamber, yet remained committed to atmospheric science for his entire career (Harrison, 2011). One of Wilson's research students, T. W. Wormell, who can be seen in Fig. 1 as a contemporary of Chalmers, and who later succeeded Wilson as leader of the Cavendish "meteorological physics" group, worked on thunderstorms. Basil Schonland, who completed a $\mathrm{PhD}$ at Cambridge on beta-rays in 1920 and then moved into atmospheric electricity, returned to Cambridge during 1927-1928 (Allibone, 1973). Schonland is even acknowledged in one of Chalmers' early papers on his radioactivity work (no. 44), so it seems hard to believe that Chalmers did not discuss atmospheric electricity with some or all of Wilson, Wormell, or Schonland. He may even have attended the lectures on the subject by Wilson as an undergraduate. Chalmers' early publications are on his thesis work, followed by a brief foray into cosmology with his brother Bruce (nos. 66 and 67). This may have been fraternal support, since Bruce was unemployed for a year after finishing a $\mathrm{PhD}$ in Physics at University College London in 1932 and appreciated scientific encouragement from his older brother (Turnbull, 1999).

The first mention of atmospheric electricity in Chalmers' publications is in an instrumentation paper, with measurement of the charge on rain as one of the applications of a new valve electrometer (no. 74). The introduction to a Masters' thesis by an early student of Chalmers (Wood, 1934) suggests inspiration from a combination of ionization and electrical conductivity of air, and the ideas of C. T. R. Wilson, both topics of which Chalmers would have been well aware 
from his time at the Cavendish. The first full atmospheric electricity paper is again on the charge on rain (no. 75) (communicated to the Physical Society by Dr. Bruce Chalmers), marking the beginning of a long and productive contribution to atmospheric electricity from Chalmers and his students at Durham.

Chalmers published 90 papers in the refereed literature between 1928 and 1967 (a full list is given in Appendix A). Some $83 \%$ of these papers were on atmospheric electricity; the rest were principally on his Cambridge radioactivity work, with occasional excursions into general physics. His preferred outlet was Journal of Atmospheric and Terrestrial Physics, in which he published 37 papers, then 15 in the Philosophical Magazine, and 14 in the Quarterly Journal of the Royal Meteorological Society. Publishing across a range of journals is still typical for researchers in an interdisciplinary subject such as atmospheric electricity. Chalmers wrote papers with a wide range of co-authors, many of whom were his students at Durham (listed in Appendix B). Perhaps the most eminent of his student collaborators was Frank Pasquill, who later became a Fellow of the Royal Society for his work on atmospheric turbulence at the Met Office (Mason and Smith, 1996). Chalmers' most prolific co-author (of four papers) was Walter Hutchinson, who was his first PhD student (Hutchinson, 1949) and who stayed at Durham, ultimately taking over the group after Chalmers' death in 1967.

Chalmers' enduringly well-known publication is the textbook, Atmospheric Electricity, first published in 1949 (no. 8). It was subsequently revised (with a new publisher) (no. 9), and the second edition was published posthumously (no. 10). This is his most highly cited work, with 88 citations. It remains one of the clearest introductions to the subject available, with a particularly extensive bibliography, though it is notable (as is much of Chalmers' work) for its lack of diagrams (Harrison, 2018).

\subsection{Analysis of publications}

Chalmers published across the whole subject of atmospheric electricity, transcending the traditional divisions between "disturbed" (i.e. lightning, thunderstorms) and "fair" (nonthunderstorm) weather. He was also equally at home with field and lab work, or theory. His research output across the subject is summarized in Fig. 2, which shows a diagram of the global atmospheric electric circuit, indicates most of the relevant processes in atmospheric electricity, and indicates how many papers he published on each aspect.

Chalmers wrote most papers (17) on point discharge, now called corona discharge. His first paper on this topic (no. 51), in 1941, was motivated by the need to understand "the earth's electrical balance sheet", which can be interpreted as how to scale up a few point discharge measurements to the current density in the global atmospheric electric circuit. (The concept of the global atmospheric electric circuit had been de-

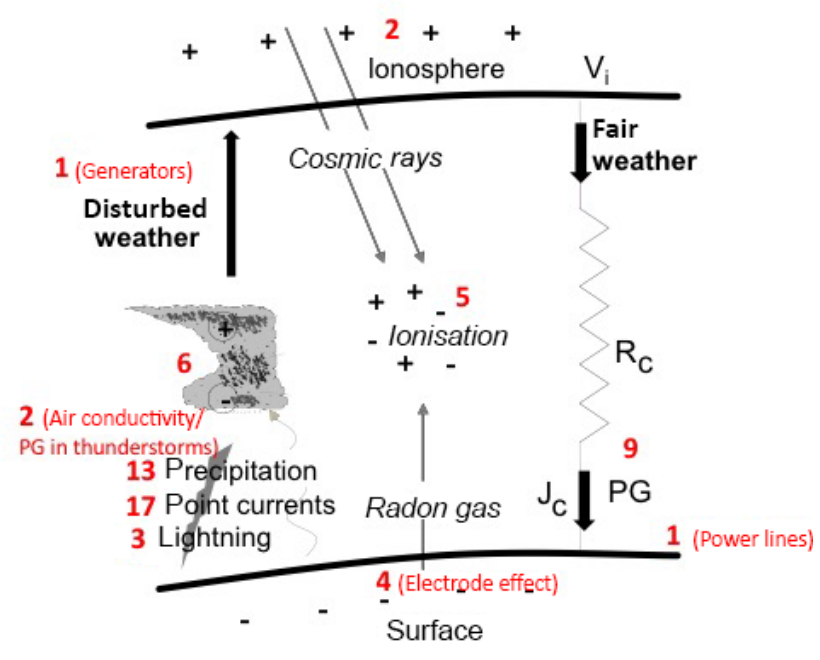

Figure 2. Concepts in atmospheric electricity (AE) (following Harrison et al., 2015), with the number of papers published by Chalmers on each topic indicated in red. Potential gradient is abbreviated to $\mathrm{PG}, \mathrm{Rc}$ the columnar resistance and Vi the ionospheric potential in the global electric circuit.

vised by C. T. R. Wilson (Aplin et al., 2008), but that name was only used to described it from about 1970 onwards, after Chalmers' death.) The 1941 paper sets out many ideas that Chalmers worked on for the rest of his life, such as corona discharge through trees. Chalmers' last paper, which was posthumously submitted, was also on the flow of current through trees (no. 84). It used the novel technique of inducing corona discharge in a small spruce tree, closely resembling a potted Christmas tree, in the laboratory (Fig. 3). The relationship between applied voltage and emitted current was found to be cubic, which was theoretically consistent with a model where the total corona current was constant with height, with a few points at the top of the tree emitting more, and more points emitting less current lower down. This relationship has been used extensively in subsequent studies of corona discharge in thunderstorms, and is still relevant, having been cited as recently as 2014. This paper also reports less conclusive measurements with a larger tree outdoors at the Durham Science Site.

Another important theme for Chalmers was the charge on precipitation, which yielded 13 papers, spanning his entire career in atmospheric electricity (1938-1967). As described earlier, Chalmers and Pasquill (no. 75) was Chalmers' first paper on atmospheric electricity, which was also motivated by the earth's electrical balance, combined with the need to understand thundercloud charging. A rain collector, supported on sulfur and ebonite insulators on the flat roof of the Durham Science Laboratories, was presumably started manually as rain began, as ". . . it was not always possible to commence observations at the beginning of the rain." This experiment found that raindrops are mainly positively charged. 


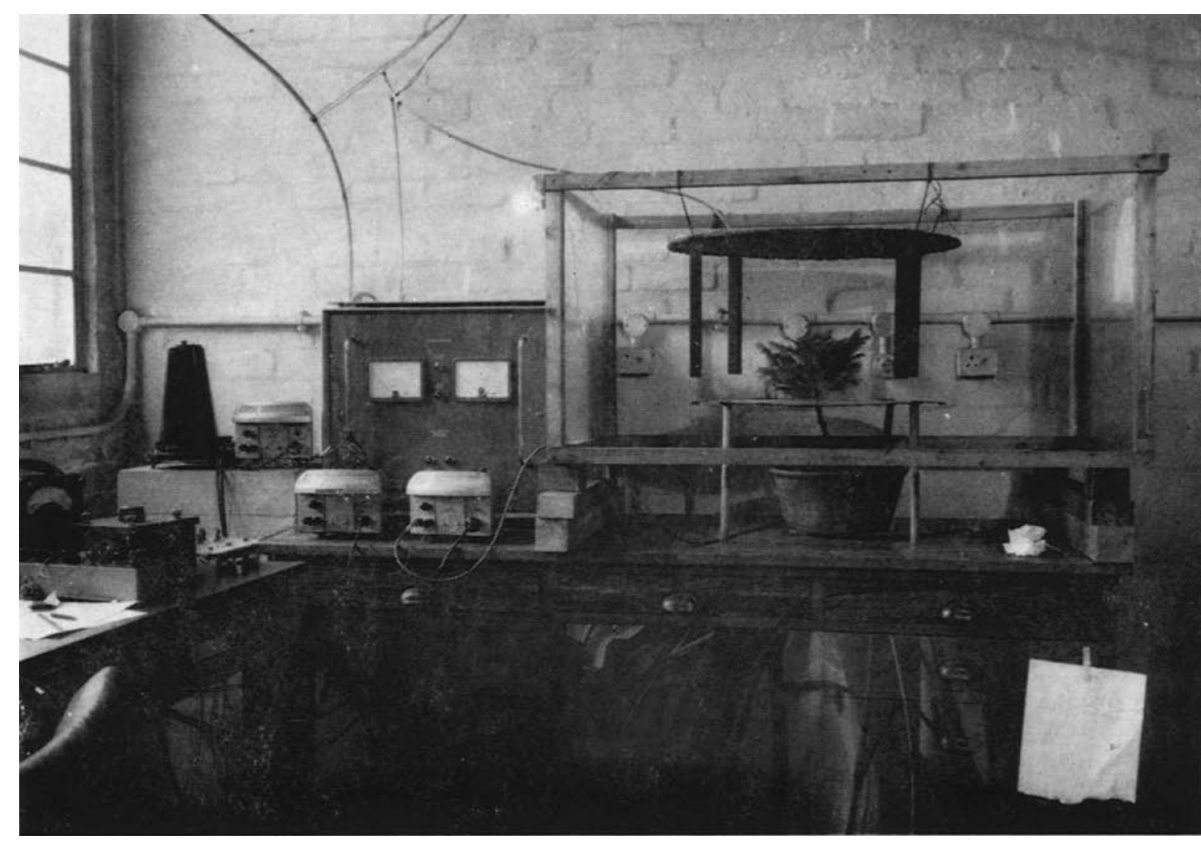

Figure 3. Experimental configuration used by Jhawar and Chalmers in 1967 (no. 84) (reproduced with permission from Elsevier). The spruce tree, seen to the right of the image, is placed between a set of electrodes to apply an electric field, and the current flow is measured.

Chalmers continued to use this technique, moving later to a collection plate (e.g. no. 61) with various corrections (e.g. no. 80), but the measurements showed substantial variability.

Chalmers' final major theme was fair weather atmospheric electricity (nine papers from 1946 to 1967). This refers to the atmospheric electricity that is present away from thunderstorm regions, for example, the electric field set up by the continual action of distant global thunderstorms, and the conduction current of ions flowing in this electric field. He began with theoretical work, mainly on the electrode effect (the build-up of positive charge near the surface's negative charge due to the conduction current). From about 1957, with the help of students and collaborators, he succeeded in measuring each of the components of the fair weather global electric circuit, specifically, the potential gradient ${ }^{6}$ (nos. 90 and 91), conduction current (no. 42), and air conductivity (no. 81). Fieldwork was mainly carried out at Durham University Observatory. The conduction current measurements are particularly noteworthy, since Chalmers resurrected the screened plate technique originally devised by Wilson (1906), which had been forgotten for 50 years (no. 42).

\subsection{Scientific legacy}

After Chalmers's death in 1967 the group at Durham was continued by Walter Hutchinson, who took on his research students, including Trevor Ogden (PhD 1967), Ian Stromberg

\footnotetext{
${ }^{6}$ The vertical atmospheric electric field $E_{z}$ is often recorded as the potential gradient $(\mathrm{PG})$, where the $\mathrm{PG}$ is regarded as $-E_{z}$. Chalmers embraced this convention in the 1957 edition of his book.
}

(PhD 1968), Mike Stringfellow (PhD 1968), William Aspinall (PhD 1969), L. Dayaratna (PhD 1969), and Graham Sharpless (PhD 1969) (William Aspinall, personal communication, 2017). There was overlap with the high-energy astroparticle physics work at Durham, with a paper studying the effects of cosmic rays on the atmospheric electric field (Curry et al., 1974). This work had been initiated by Chalmers, no doubt encouraged by shared interests with his Durham colleague Arnold Wolfendale (Harrison, 2018); these early results were inconclusive but established some constraints which did later lead to successful measurements (William Aspinall, personal communication, 2017; Dayaratna, 1969).

Some aspects of Chalmers' work were left unfinished because of his early death. It is surprising that no attempt was made to combine Chalmers' measurements of the three parameters of the global electric circuit described in Sect. 3.1; it seems hard to believe that this would not have happened, had Chalmers lived for longer. Simultaneous measurement of the atmospheric conduction current, potential gradient, air conductivity, and space charge was achieved for 1 year from July 1967, soon after Chalmers' death, by Sharpless (1968). These measurements took place at Lanehead field station in the North Pennines, away from the pollution which was starting to become evident at Durham University Observatory (e.g. no. 94). This suggests that Chalmers, who supervised the first part of Sharpless' project, had been planning further work on the global circuit, since global parameters become obscured at polluted sites (e.g. Harrison and Aplin, 2002). Sharpless (1968) successfully demonstrated that the 
potential gradient at the Lanehead site closely followed the Carnegie curve, the universal daily variation in potential gradient controlled by the worldwide distribution of thunderstorms, and would therefore have been suitable for further studies of the global electric circuit. Unfortunately however, little more work seems to have been done, perhaps reflecting the difficulty in keeping a multi-instrumented remote site fully operational.

Chalmers was also ultimately unsuccessful in his analysis of the near-surface atmospheric electrical profiles, known as the electrode effect. Theoretical studies of the electrode effect were continued in parallel with experimental work, but Chalmers was unable to obtain the analytical solution that he wanted. A former research student, Derek Lane-Smith (personal communication, 2017) describes Chalmers seeking his opinion on the electrode effect work, but he felt there was little he could add. Peter Wildman (personal communication, 2017) recalls that Chalmers had a legendary understanding of physics, and was known for politely correcting the mistakes made by visiting speakers in seminars, so this may explain the reticence of a research student to contribute beyond his own thesis topic. The electrode effect equations Chalmers pursued had been independently solved by Law (1963) with an early computer in a paper communicated to the Royal Meteorological Society by Wormell on 23 July 1962. As Wormell examined Wildman's PhD thesis, submitted in June 1962, Chalmers would almost certainly have been aware that the electrode effect had already been solved numerically. Despite this, he persisted in searching for an analytical solution until his death (no. 65), illustrating his strong background in theoretical and experimental physics. Such determination had served Chalmers well during a career spent making measurements with sensitive instrumentation under difficult conditions, but in this case this did not lead to a successful theoretical outcome.

Chalmers was trained in the great tradition of experimental physics at the Cavendish Laboratory, underpinned by strong theoretical awareness. He brought this approach north to Durham University, which, soon afterwards, established its own Physics Department. He tirelessly investigated problems across the whole of atmospheric electricity, but his most influential contributions are probably his textbook, and his work on corona currents. The textbook is still widely read and is still one of the most accessible introductions to the area, written with clarity and rigour. His research on corona currents laid the modern foundations of the topic, particularly the polynomial relationship between voltage and current which is still regularly referred to. $\mathrm{He}$ was also a supportive mentor and effective supervisor for his numerous graduate students, many of whom became successful scientists in the UK and worldwide. These students clearly held "Skip" Chalmers in high regard, as can be seen in the acknowledgements sections of the theses collated in Appendix B, and was clear in recent discussions with his former students (e.g. William Aspinall, personal communi- cation, 2017; Derek Lane-Smith, personal communication, 2017; Peter Wildman, personal communication, 2017).

\section{Atmospheric electricity in the UK after Chalmers}

Atmospheric electricity was to continue at Durham until Hutchinson's retirement in the late 1970s, with postChalmers additions to the group including several research students and a postdoctoral research associate, Gerry Jennings. Atmospheric electricity, or "Meteorological Physics", had faded at Cambridge after Wormell's retirement in the early 1970s. Like Hutchinson, Wormell worked with many notable meteorologists and atmospheric electricians, including Michael Rycroft (PhD 1963, subsequently at Southampton and the British Antarctic Survey), Mike Pedder ( $\mathrm{PhD}$ 1969), and Anthony Illingworth (PhD 1970). The only atmospheric electricity work in the UK during the 1980s and early 1990s was led by Clive Saunders and Anthony Illingworth at Manchester. Later, the Meteorology Department at the University of Reading became home to a revival of the subject led by Giles Harrison from the 1990s. (Both Mike Pedder and Anthony Illingworth also worked at Reading for many years.) There are now active research programmes in atmospheric electricity at Reading, Bath, Bristol, Cardiff, Oxford, and St Andrews universities, covering both "fair" and "disturbed" weather as well as atmospheric electrical effects on biological systems and on other planets, with considerable industrial involvement. Regular meetings are now held by an Atmospheric Electricity Special Interest Group of the Royal Meteorological Society.

Data availability. The publication data used in this paper were obtained by searching the Web of Science database and Google Scholar in May 2017. 
Appendix A: Full Chalmers bibliography of refereed papers and textbook (alphabetical order by author, then paper title)

1. Bent, R. B., Collin, H. L., Hutchinson, W. C., and Chalmers, J. A.: Space charges produced by point discharge from trees during a thunderstorm, J. Atmos. Terr. Phys., 27, 1, 67 (1965)

2. Chalmers, J. A.: A difficulty in elementary electromagnetism, Contemp. Phys., 5, 4, 292 (1964)

3. Chalmers, J. A.: A new method of measuring the vertical electric field in the atmosphere, J. Sci. Inst. Phys. Industry, 26, 9, 300 (1949)

4. Chalmers, J. A.: A note on theories of the electric fields below clouds, Quart. Roy. Met. Soc., 65, 280, 237 (1939)

5. Chalmers, J. A.: Absorption measurements and the continuous spectrum of beta-rays, Proc. Camb. Phil. Soc., 28, 3, 319 (1932)

6. Chalmers, J. A.: An approximate method of determining the high-velocity limits of continuous beta-ray spectra, Proc. Camb. Phil. Soc., 25, 3, 331 (1929)

7. Chalmers, J. A.: Atmospheric electrical conductivity near the earth's surface, J. Atmos. Terr. Phys., 3, 4, 223 (1953)

8. Chalmers, J. A.: Atmospheric Electricity, Oxford: Clarendon Press (1949)

9. Chalmers, J. A.: Atmospheric Electricity, Oxford: Pergamon Press (1957)

10. Chalmers, J. A.: Atmospheric Electricity, 2nd edition, Oxford: Pergamon Press (1967)

11. Chalmers, J. A.: Atmospheric electricity, Rep. Prog. Phys., 17, 101 (1954)

12. Chalmers, J. A.: Cloud and earth lightning flashes, Phil. Mag., 32, 210, 77 (1941)

13. Chalmers, J. A.: Contact potentials - part I. general principles, Phil. Mag., 33, 221, 399 (1942)

14. Chalmers, J. A.: Contact potentials - part II. the volta effect, Phil. Mag., 33, 221, 416 (1942)

15. Chalmers, J. A.: Contact potentials - part III. the voltaic cell, Phil. Mag., 33, 222, 496 (1942)

16. Chalmers, J. A.: Contact potentials - part IV. the concentration cell, Phil. Mag., 33, 222, 506 (1942)

17. Chalmers, J. A.: Contact potentials - part V. the metalelectrolyte Volta effect, Phil. Mag., 33, 223, 594 (1942)
18. Chalmers, J. A.: Contact potentials - part VI. single potential differences, Phil. Mag., 33, 223, 599 (1942)

19. Chalmers, J. A.: Contact potentials - part VII. chemical and thermal effects, Phil. Mag., 33, 223, 608 (1942)

20. Chalmers, J. A.: Criterion for thunderstorm theories, J. Atmos. Terr. Phys., 21, 02-Mar, 174 (1961)

21. Chalmers, J. A.: Difference between a current-carrying coil and a permanent magnet, Contemp. Phys., 7, 6, 468 (1966)

22. Chalmers, J. A.: Effect of wind on point-discharge pulses, J. Atmos. Terr. Phys., 27, 10, 1037 (1965)

23. Chalmers, J. A.: Electric charges from ice friction, J. Atmos. Terr. Phys., 2, 6, 337 (1952)

24. Chalmers, J. A.: Electrical properties of a living tree in relation to point discharge, J. Atmos. Terr. Phys., 26, 1, 129 (1964)

25. Chalmers, J. A.: Energy problems in the continuous spectrum of beta-rays, Proc. Camb. Phil. Soc., 28, 3, 328 (1932)

26. Chalmers, J. A.: First suggestion of an ionosphere, J. Atmos. Terr. Phys., 24, 3, 219 (1962)

27. Chalmers, J. A.: Further comments, J. Geophys. Res., 69, 2, 362 (1964)

28. Chalmers, J. A.: Generators in atmospheric electricity, Pageophysics, 57, 189 (1964)

29. Chalmers, J. A.: Induced charges and the fine-weather field, J. Atmos. Terr. Phys., 4, 1-2, 84 (1953)

30. Chalmers, J. A.: Ionisation measurements of gammarays, Phil. Mag., 6, 38, 745 (1928)

31. Chalmers, J. A.: Measurement of vertical electric current in atmosphere, J. Atmos. Terr. Phys., 24, 4, 297 (1962)

32. Chalmers, J. A.: Negative electric fields in mist and fog, J. Atmos. Terr. Phys., 2, 3, 155 (1952)

33. Chalmers, J. A.: Negative electric fields in the atmosphere, Nature, 169, 4295, 336 (1952)

34. Chalmers, J. A.: Note on the calculation of the Peltier effect, Proc. Camb. Phil Soc., 35, 3, 521 (1939)

35. Chalmers, J. A.: On conductivity of air in thunderstorms, J. Geophys. Res., 69, 2, 357 (1964)

36. Chalmers, J. A.: Some problems in radioactivity, $\mathrm{PhD}$ Thesis, University of Cambridge (1930) 
37. Chalmers, J. A.: Point discharge currents, J. Atmos. Terr. Phys., 2, 5, 301 (1952)

38. Chalmers, J. A.: Point-discharge current, potential gradient and wind-speed, J. Atmos. Terr. Phys., 11, 3-4, 301 (1957)

39. Chalmers, J. A.: Point-discharge currents through a living tree during a thunderstorm, J. Atmos. Terr. Phys., 24, 1059 (1962)

40. Chalmers, J. A.: Positive charges from earth and maintenance of earth's fine-weather potential gradient, J. Atmos. Terr. Phys., 29, 3, 307 (1967)

41. Chalmers, J. A.: Relation between precipitation current and potential gradient, J. Atmos. Terr. Phys., 27, 8, 899 (1965)

42. Chalmers, J. A.: Relation of point-discharge current to potential difference and wind-speed, J. Atmos. Terr. Phys., 24, 5, 339 (1962)

43. Chalmers, J. A.: So-called induction component in electric field of a lightning discharge, J. Atmos. Terr. Phys., 27, 9, 1027 (1965)

44. Chalmers, J. A.: The absorption of beta-rays, Proc. Camb. Phil. Soc., 26, 2, 252 (1930)

45. Chalmers, J. A.: The agrimeter for continuous recording of the atmospheric electric field, J. Atmos. Terr. Phys., 4, 3, 124 (1953)

46. Chalmers, J. A.: The capture of ions by ice particles, Quart. J. Roy. Met. Soc., 73, 317, 324 (1947)

47. Chalmers, J. A.: The charge on the ionosphere, J. Atmos. Terr. Phys., 3, 6, 345 (1953)

48. Chalmers, J. A.: The charging of rain by splashing, Quart. J. Roy. Met. Soc., 81, 350, 618 (1955)

49. Chalmers, J. A.: The correspondence between a currentcarrying coil and a magnetic dipole, Contemp. Phys., 2, 42922, 472 (1961)

50. Chalmers, J. A.: The effective separation of discharging points, J. Atmos. Terr. Phys., 3, 6, 346 (1953)

51. Chalmers, J. A.: The effective separation of points discharging atmospheric electricity, Phil. Mag., 31, 208, 363 (1941)

52. Chalmers, J. A.: The electrical charge on the earth, J. Atmos. Terr. Phys., 8, 01-Feb, 124 (1956)

53. Chalmers, J. A.: The electricity of precipitation, Br. J. App. Phys., 12, NA, 372 (1961)
54. Chalmers, J. A.: The ionisation in the lowest regions of the atmosphere, Quart. J. Roy. Met. Soc., 72, 312, 199 (1946)

55. Chalmers, J. A.: The laws of electromagnetism and an electrostatic analogue, Contemp. Phys., 3, 4, 278 (1962)

56. Chalmers, J. A.: The origin of the electric charge on rain, Quart. J. Roy. Met. Soc., 77, 332, 249 (1951)

57. Chalmers, J. A.: The reflexion of beta-rays, Phil. Mag., $25,167,322$ (1938)

58. Chalmers, J. A.: The relation between point discharge current and field, J. Atmos. Terr. Phys., 2, 5, 292 (1952)

59. Chalmers, J. A.: The separation of electricity in clouds, Phil. Mag., 34, 228, 63 (1943)

60. Chalmers, J. A.: The single potential difference at a cadmium electrode, Phil. Mag., 34, 232, 349 (1943)

61. Chalmers, J. A.: The vertical electric current during continuous rain and snow, J. Atmos. Terr. Phys., 9, 56, $311(1956)$

62. Chalmers, J. A.: Theory of electrode effect 1: method and simple example, J. Atmos. Terr. Phys., 28, 6-7, 565 (1966)

63. Chalmers, J. A.: Theory of electrode effect 2: inclusion of condensation nuclei, J. Atmos. Terr. Phys., 28, 06-Jul, 573 (1966)

64. Chalmers, J. A.: Theory of electrode effect 3: restriction of assumptions, J. Atmos. Terr. Phys., 28, 10, 1029 (1966)

65. Chalmers, J. A.: Theory of electrode effect 4: variation of ionization with height, J. Atmos. Terr. Phys., 29, 2, 217 (1967)

66. Chalmers, J. A. and Chalmers, B., Age of the universe, Nature, 136, NA, 916 (1935)

67. Chalmers, J. A. and Chalmers B.: The expanding universe-an alternative view, Phil. Mag., 19, 126, 436 (1935)

68. Chalmers, J. A. and Ette, A. I. I.: Some measurements of point-discharge currents between negative point and positive plane, J. Atmos. Terr. Phys., 28, 1, 111 (1966)

69. Chalmers, J. A. and Hutchinson, W. C. A.: Negative electric fields in the atmosphere, Nature, 164, 4158, 68 (1949)

70. Chalmers, J. A. and Little, E. W.: Electric charge on soft hail, Nature, 143, NA, 244 (1939) 
71. Chalmers, J. A. and Little, E. W.: The electricity of continuous rain, Terrestrial Magnetism and Atmospheric Electricity, 45, 4, 451 (1940)

72. Chalmers, J. A. and Mapleson W. W.: Point discharge currents from a captive balloon, J. Atmos. Terr. Phys., $6,1-6,149(1955)$

73. Chalmers, J. A., Mason, B. J., Penman, H. L., and Hutchinson, W. C. A.: The electrification of freezing water droplets and of colliding ice particles, Quart. J. Roy. Met. Soc., 90, 386, 487 (1964)

74. Chalmers, J. A. and Pasquill, F.: A valve amplifier for the measurement of small charges, J. Sci. Instrum., 14, 4, 127 (1937)

75. Chalmers, J. A. and Pasquill, F.: The electric charges on single raindrops and snowflakes, Proc. Phys. Soc., 50, $1,1(1938)$

76. Chalmers, J. A. and Pasquill, F.: The potential difference at an air-water interface, Phil. Mag., 23, 152, 88 (1937)

77. Collin, H. L., Raisbeck, I. A., and Chalmers, J. A.: Measurements of atmospheric electricity at top and foot of a $25 \mathrm{~m}$ mast, J. Atmos. Terr. Phys., 25, 11, 631 (1963)

78. Groom, K. N. and Chalmers, J. A.: Current through radioactive point in atmosphere, J. Atmos. Terr. Phys., 26, 5,603 (1964)

79. Groom, K. N. and Chalmers, J. A.: Negative charges from high-tension power cables in fog, J. Atmos. Terr. Phys., 29, 5, 613 (1967)

80. Groom, K. N. and Chalmers, J. A.: Relation between rain current and potential gradient, J. Atmos. Terr. Phys., 29, 7, 877 (1967)

81. Higazi, K. A. and Chalmers, J. A.: Measurements of atmospheric electrical conductivity near ground, J. Atmos. Terr. Phys., 28, 3, 327 (1966)

82. Hutchinson, W. C. A. and Chalmers, J. A.: The electric charges and masses of single raindrops, Quart. J. Roy. Met. Soc., 77, 331, 85 (1951)

83. Jhawar, D. S. and Chalmers, J. A.: Point discharge from multiple points, J. Atmos. Terr. Phys., 27, 3, 367 (1965)

84. Jhawar, D. S. and Chalmers, J. A.: Point-discharge currents through small trees in artificial fields, J. Atmos. Terr. Phys., 29, 11, 1459 (1967)

85. Kirkman, J. R. and Chalmers, J. A.: Point discharge from an isolated point, J. Atmos. Terr. Phys., 10, 5-6, 258 (1957)
86. Maund, J. E. and Chalmers, J. A.: Point-discharge currents from natural and artificial points, Quart. J. Roy. Met. Soc., 86, 367, 85 (1960)

87. Milner, J. W. and Chalmers, J. A.: Point discharge from natural and artificial points, Quart. J. Roy. Met. Soc., 87, 374, 592 (1961)

88. Owolabi, I. E. and Chalmers, J. A.: Correlations of precipitation currents, J. Atmos. Terr. Phys., 27, 3, 303 (1965)

89. Ramsay, M. W. and Chalmers, J. A.: Measurements on the electricity of precipitation, Quart. J. Roy. Met. Soc., $86,370,530(1960)$

90. Smiddy, M. and Chalmers, J. A.: Measurements of space charge in the lower atmosphere using double field mills, Quart. J. Roy. Met. Soc., 86, 367, 79 (1960)

91. Smiddy, M. and Chalmers, J. A.: The double field-mill, J. Atmos. Terr. Phys., 12, 2-3, 206 (1958)

92. Smith, L. G., Jones, R. F., Chalmers, J. A., and Pierce, E. T.: Intracloud lightning discharges, Quart. J. Roy. Met. Soc., 84, 361, 288 (1958)

93. Whipple, F. J. and Chalmers, J. A.: On Wilson's theory of the collection of charge by falling drops, Quart. J. Roy. Met. Soc., 70, 304, 103 (1944)

94. Whitlock, W. S. and Chalmers, J. A.: Short-period variations in the atmospheric electric potential gradient, Quart. J. Roy. Met. Soc., 82, 353, 325 (1956)

Appendix B: Research students of J. A. Chalmers, thesis title, and degree awarded (chronological order)

All theses held at Durham University Library have been digitized and are available at http://etheses.dur.ac.uk.

- Wood, H. P. (1934) The electric charge on rain and the breaking drop theory of its origin, MSc

- Pasquill, F. (1935) (Postgraduate research fellowship: no degree awarded)

- Hutchinson W. (1949) The electric charges and masses of rain drops, $\mathrm{PhD}$

- Kay, A. E. (1950) The application of electronic methods to measurements in atmospheric electricity, $\mathrm{PhD}$

- Mapleson, W. (1953) Point discharge in atmospheric electricity, $\mathrm{PhD}$

- Whitlock, W. S. (1955) Variations in the earth's electric field, $\mathrm{PhD}$ 
- Kirkman, J. R. (1956) Point discharge in atmospheric electricity, $\mathrm{PhD}$

- Smiddy, M. (1958) Measurement of space charge in the lower atmosphere, $\mathrm{PhD}$

- Adamson, J. (1958) The compensation of the effects of potential gradient variations in the measurement of the atmospheric air-earth current, $\mathrm{PhD}$

- Maund, J. E. (1958) Point discharge in atmospheric electricity, $\mathrm{PhD}$

- Merry, G. H. (1959) Measurements of precipitation electricity, MSc

- Ramsay, M. W. (1959) The relation between precipitation current, potential gradient, and rate of precipitation, $\mathrm{PhD}$

- Milner, J. W. (1960) Measurements of atmospheric point discharge currents, $\mathrm{PhD}$

- Collin, H. L. (1962) Observations of the variation of precipitation electricity with height, MSc

- Evans, D. G. (1962) The electrification of ice and supercooled water drops, MSc

- Wildman, P. J. L. (1962) The development of the apparatus to measure electric field in the presence of ionisation, $\mathrm{PhD}$

- Groom, K. N. (1963) The relation between radio-active collector current potential gradient and wind speed, MSc

- Raisbeck, I. A. (1963) Measurements in atmospheric electricity in a vertical plane, MSc

- Owolabi, I. E. (1964) Investigation of correlations of precipitation electricity to different receivers, $\mathrm{PhD}$

- Bent, R. B. (1964) The electrical space charge in the lower atmosphere, $\mathrm{PhD}$

- Higazi, K. A. (1965) Conductivity measurements near the ground, $\mathrm{PhD}$

- Nicholl, B. (1965) A survey of the levels of lightning and thunderstorm activity in Sierra Leone, MSc

- Church, C. R. (1966) The electrification of hail, PhD

- Darsley, R. R. (1966) Practical considerations in the reconciliation of the direct and indirect methods or measuring the air-earth current, MSc

- Groom, K. N. (1966) Disturbed weather measurements in atmospheric electricity using an instrumented van, $\mathrm{PhD}$

- Jhawar, D. S. (1967) Measurements of natural and artificial point discharge, $\mathrm{PhD}$
Projects initiated by Chalmers but passed to Hutchinson after Chalmers' death

- Rogers, L. N. (1967) The electrification of water drops on freezing or belting at terminal velocity in air, $\mathrm{PhD}$

- Ogden, T. L. (1967) Electric space-charge measurements in convective and other weather conditions, $\mathrm{PhD}$

- Sharpless, G. T. (1968) An experimental study of the atmospheric electric elements at a rural site in conditions of low air pollution, $\mathrm{PhD}$

- Stromberg, I. M. (1968) Point discharge pulse measurements in atmospheric electricity, $\mathrm{PhD}$

- Collin, H. L. (1969) vol 1: An investigation of atmospheric electrical phenomena within $22 \mathrm{~m}$ of the ground during disturbed weather; vol 2: The ground based study of clouds, $\mathrm{PhD}$

- Dawson, R. (1969) The electrification of ice and water at temperatures around the freezing point, $\mathrm{PhD}$

- Dayaratna, L. H. (1969) Atmospheric electric conduction and convection currents near the earth's surface, $\mathrm{PhD}$

- Stringfellow, M. F. (1969) The electrical structure of nimbostratus clouds, $\mathrm{PhD}$

- Lane-Smith, D. R. (1969) Electrical Processes in Heavy Rain in the Tropics, PhD 
Competing interests. The author declares that she has no conflict of interest.

Acknowledgements. I would like to thank Jacob Butler and Malcolm Longair FRS of the Cavendish Laboratory Museum at Cambridge University for their assistance in sourcing a photograph of Chalmers. Michael Stansfield at Palace Green Library and Archive, Durham University, provided electronic versions of files from the University Archive, and Heather Ewington at the Bill Bryson Library, Durham University, explained Durham's thesis digitization project. Michele Losse, the archivist at Highgate School, supplied invaluable information on Chalmers' early life. This paper was inspired by a Royal Meteorological Society meeting commemorating the 50th anniversary of Chalmers' death held at Durham University Physics Department in May 2017, which was attended by, and has encouraged contact with, several of Chalmers' former colleagues.

Edited by: Hans Volkert

Reviewed by: two anonymous referees

\section{References}

Allibone, T. E.: Basil Ferdinand Jamieson Schonland, 1896-1972, Biog. Mem. Fellows Royal Soc., 19, 629-653, 1973.

Aplin, K. L., Harrison, R. G., and Rycroft, M. J.: Investigating Earth's atmospheric electricity: a role model for planetary studies, Space Sci. Revi., 137, 11-27, https://doi.org/10.1007/s11214-008-9372-x, 2008.

Bloomfield, G. W.: Some investigations on the electrification of interfaces, $\mathrm{PhD}$ thesis, University of Durham, available at: http: //etheses.dur.ac.uk/9199/, 1948.

Browning K. A.: Sir (Basil) John Mason CB, 18 August 1923-6 January 2015, Biog. Mem. Fellows Royal Soc., 62, 359-380, https://doi.org/10.1098/rsbm.2015.0028, 2015.

Census: 1911 Census of England, London, Stephen Chalmers household, Digital image GBC_1911_RG14_07205_0537.jpg, available at: http://www.1911 census.co.uk (last access: 3 January 2018), 1911.

Curry, A., Kannangara, M. L. T., and Turver, K. E.: The effects of large extensive air showers on the Earth's atmospheric electric field, J. Atmos. Sol.-Terr. Phy., 36, 215-224, 1974.

Dayaratna, L. H.: Atmospheric electric conduction and convection currents near the earth's surface, PhD Thesis, Durham University, available at: http://etheses.dur.ac.uk/8692/, 1969.

Durham University Archive: Papers from Statutory Committee on the Personal Professorships in Physics, including statements from Head of Department and external referees, Palace Green Library Special Collections, reference UND/CB1/P2b, 1965.

Durham University Archive: Introduction to Administrative History, Palace Green Library Special Collections, reference GB0033-UND/D, 2008.
Harrison, R. G.: The cloud chamber and CTR Wilson's legacy to atmospheric science, Weather, 66, 276-279, https://doi.org/10.1002/wea.830, 2011.

Harrison, R. G.: Atmospheric Electricity at Durham (27 May 2017), Weather, 73, 82-83, https://doi.org/10.1002/wea.3197, 2018.

Harrison, R. G. and Aplin, K. L.: Mid-nineteenth century diurnal smoke concentrations near London, Atmos. Environ., 36, 40374043, https://doi.org/10.1016/j.atmosenv.2003.09.042, 2002.

Harrison, R. G., Nicoll, K. A., and Ambaum, M. H. P.: On the microphysical effects of observed cloud edge charging, Q. J. Roy. Meteorol. Soc., 141, 2690-2699, 2015.

Holzer, R. E. and Smith, W. E.: Proceedings on the Conference on Atmospheric Electricity, Geophysical Research Papers, No. 42, Air Force Cambridge Research Center (AD 084 477), available at: http://www.dtic.mil/dtic/tr/fulltext/u2/084477.pdf, 1955.

Hutchinson, W. C. A.: The electric charges and masses of rain drops, $\mathrm{PhD}$ Thesis, University of Durham, available at: http: //etheses.dur.ac.uk/8961/, 1949.

Law, J.: The ionisation of the atmosphere near the ground in fair weather, Q. J. Roy. Meteorol. Soc., 89, 107-121, 1963.

Longair, M.: Maxwell's Enduring Legacy: a scientific history of the Cavendish Laboratory, Cambridge University Press, 650 pp., 2016.

Mason, B. J. and Smith, F. B.: Frank Pasquill, 8 September 1914 15 October 1994, Biog. Mem. Fellows Royal Soc., 42, 277-288, https://doi.org/10.1098/rsbm.1996.0018, 1996.

Rochester, G. D. and Hutchinson, W. C. A.: Professor J. A. Chalmers, Nature 215, p. 795, https://doi.org/10.1038/215795b0, 1967.

Sharpless, G. T.: An experimental study of the atmospheric electric elements at a rural site in conditions of low air pollution, $\mathrm{PhD}$ Thesis, University of Durham, available at: http://etheses.dur.ac. uk/8744/, 1968.

Smith, L. G. (Ed.): Recent advances in atmospheric electricity, Pergamon Press, London, 631 pp., 1958.

The Cholmeleian: Alumni magazine for Highgate School, further information available from: https://www.highgateschool.org.uk/ oc/alumni-about-us (last access: 3 March 2018), 1923a.

The Cholmeleian: Alumni magazine for Highgate School, further information available from: https://www.highgateschool.org.uk/ oc/alumni-about-us (last access: 3 March 2018), 1923 b.

Tuck, D. G.: A memoir concerning the Londonderry Laboratory for Radiochemistry at the University of Durham, unpublished document available at: http://chemistry-alumni dur.ac.uk/lib/exe/fetch.php?media=research_groups: dh1-3le_paneth-tuck_02-14.pdf (last access: 3 November 2017), 1995.

Turnbull, D.: Bruce Chalmers 1907-1990: Biographical Memoir, Nat. Acad. Press, Washington DC, 1999.

Wilson, C. T. R.: On the measurement of the earth-air current and on the origin of atmospheric electricity, Proc. Camb. Philos. Soc., 13, 363-382, 1906.

Wood, H. P.: The electric charge on rain and the "breaking drop" theory of its origin, MSc Thesis, University of Durham, available at: http://etheses.dur.ac.uk/10361/, 1934. 